\title{
Sprawozdanie z konferencji pt. Międzymorze. Historia, polityka, prawo, Lódź, 22 stycznia 2017 r.
}

W dniu 22 stycznia 2017 r. w Sali Rady Wydziału Filozoficzno-Historycznego Uniwersytetu Łódzkiego (dalej: UŁ) odbyła się konferencja naukowa pt. Międzymorze. Historia, polityka, prawo. Organizatorami spotkania był Uniwersytet Eódzki oraz Fundacja Wspierania Inicjatyw Obywatelskich, natomiast patronat honorowy objęli: Wojewoda Łódzki, Jego Magnificencja Rektor Uniwersytetu Łódzkiego, Dziekan Wydziału Filozoficzno-Historycznego, a także Ministerstwo Spraw Zagranicznych, Ministerstwo Obrony Narodowej oraz Ministerstwo Kultury i Dziedzictwa Narodowego. Wśród patronów medialnych znalazły się natomiast m.in. Telewizja Polska Historia, Telewizja Toya, Radio Łódź oraz periodyki: „W Sieci Historii”, „Tygodnik Solidarnośč” i „Dziennik Łódzki”.

Celem konferencji była dyskusja nad uwarunkowaniami historycznymi, politycznymi i prawnymi idei Międzymorza, a także nawiazanie współpracy przez uczestników forum. Spotkanie - zgodnie z zapowiedziami organizatorów - ma zostać zwieńczone wydaniem pierwszego numeru kwartalnika „Międzymorze. Historia, polityka, prawo", którego publikacji ma się podjąc Fundacja Wspierania Inicjatyw Obywatelskich wspólnie $z$ Instytutem Historii przy współudziale Wydziału Prawa i Administracji UŁ oraz Wydziału Studiów Międzynarodowych i Politologicznych UŁ.

Konferencję otworzył profesor Przemysław Waingertner, który wygłosił referat zatytułowany „Polskie” Międzymorze - studium przypadku romantycznej realpolitik. W swoim wystapieniu zwrócił uwagę na problematykę idei Międzymorza $z$ punktu widzenia polskich koncepcji i dażeń politycznych. Zaprezentowano genezę, okoliczności i konsekwencje podejmowanych prób zabezpieczenia 
granic Polski na przestrzeni wieków, a także polskie wysiłki w sferze budowy własnej pozycji na arenie międzynarodowej. Autor w swoim tekście zawarł krótki rys historyczny przypominajacy m.in. tworzenie pierwszych unii personalnych $z$ udziałem Polski, założenia polityczne II Rzeczpospolitej oraz koncepcje polskiej emigracji po klęsce kampanii wrześniowej 1939 r. Myśla przewodnią wystąpienia było podkreślenie wskazania przez polską dyplomację jako celu maksymalistycznego budowy Międzymorza w warunkach rosnacego zagrożenia ze strony wschodniego i zachodniego sąsiada. Obrona suwerenności państwa sprawiała jednak, że cel ten, z pozoru abstrakcyjny, stawał się polska racją stanu.

Następnie swój referat Miejsce Ukrainy $w$ idei Międzymorza zaprezentował profesor Jacek Reginia-Zacharski. W wystapieniu przedstawił Ukrainę w kontekście badań podmiotów międzynarodowych, współdziałających w zakresie tworzenia idei Intermarium, oraz teorię aliansowości, będącą wynikiem analizy związków obronnych i ofensywnych, która dowodzi nadrzędności systemów zabezpieczających przed ewentualnym konfliktem zbrojnym. Konsekwencja tych poglądów w sferze bezpieczeństwa międzynarodowego jest stworzenie sojuszu, mającego na celu zrównoważenie potencjału przeciwnika. Główną tezą referatu było ukazanie idei Międzymorza jako potencjału, a nie tworu geopolitycznego, w którym Ukraina $z$ innymi państwami tworzy przeciwwagę dla Rosji i Niemiec na kontynencie europejskim.

Profesor Andrzej Dubicki zaprezentował problem Rumuńskiego podejścia do Międzymorza. W swoim referacie omówił zmiany zachodzace na arenie międzynarodowej, których konsekwencją było zainteresowanie kwestia zawiazania porozumienia w celu zabezpieczenia własnego państwa przed rosnacym zagrożeniem ze strony Federacji Rosyjskiej. Badacz zwrócił uwagę na różnorodność interesów państw zaangażowanych pracami nad koncepcją Międzymorza po aneksji Krymu, które również zagrażają interesom Rumunii. W referacie zaprezentował najważniejsze zagadnienia i kierunki polityki zagranicznej Bukaresztu po zakończeniu II wojny światowej, a także koncepcje zabezpieczenia terenów Morza Bałtyckiego, Morza Czarnego i Morza Adriatyckiego.

Z kolei doktor Michał Rulski omówił zagadnienie Minilateralizm jako naprawa multilateralizmu - przypadek "nowej Europy” na forum UE. Autor przedstawił podstawowe założenia funkcjonowania polityki międzynarodowej, natomiast minilateralizm został ukaza- 
ny jako próba utworzenia $z$ niewielkiej liczby państw bloku równowagi sił na kontynencie europejskim. Wspomniane w wystapieniu założenia składają się na obecny kierunek polskiej polityki zagranicznej na forum Unii Europejskiej. Swoim referatem badacz chciał wskazać możliwość nowego pola dyskusji naukowej, a także postrzegania fundamentów polityki międzynarodowej Rzeczpospolitej.

Następnie swój referat - Koncepcja Międzymorza $w$ programie i praktyce politycznej KPN 1989-1997-przedstawił doktor Tomasz Szczepański. Autor rozważał pozycję idei Międzymorza w wystąpieniach programowych i politycznej Konfederacji Polski Niepodległej. Omówiono zabiegi polityków mających na celu propagowanie założeń partii, jak i wszelkie projekty organizacyjne. Rozpatrzono również przyczyny zaniku koncepcji Międzymorza w programach politycznych na przełomie XX i XXI w.

Ostatnim wystapieniem był referat magistra Jakuba Spychalskiego pt. Prawne formy wspótpracy na gruncie prawa międzynarodowego. Autor dokonał analizy prawnych form kooperacji państw na arenie międzynarodowej. Przedstawił koncepcje konfederacyjne, federacyjne oraz funkcjonalne - będące podstawą współczesnej Unii Europejskiej. Rozważania badacza miały ukazać najodpowiedniejszą formę współdziałania państw w ramach idei Międzymorza. Referent zaprezentował także wspólne interesy krajów zrzeszonych w Grupie Wyszehradzkiej.

Zakończenie konferencji przeniosło część rozważań na grunt współczesnej debaty, jaka toczy się w chwili rosnącego zagrożenia ze strony Federacji Rosyjskiej, a także koncepcji mających zaprowadzić równowage sił na kontynencie europejskim. Uczestnicy spotkania podkreślili zasadność przeprowadzonej dyskusji. Zasygnalizowali również możliwość podjęcia w przyszłości współpracy naukowej wokół zagadnień konferencji.

ŻANETA BOROWIAK UNIWERSYTET ŁÓDZKI*

* Wydział Filozoficzno-Historyczny, Studia Doktoranckie Nauk Humanistycznych, e-mail: zabeta16@wp.pl. 